\title{
Vitamin D receptor gene polymorphisms and its interactions with environmental factors on renal cell carcinoma risk
}

\author{
Tian Jianhai, Lv Jian, Zhang Long, Wang Wei, Zhang Shumao, Wang Yiming and Li Xiaojuan*
}

\begin{abstract}
Aims: We designed a case-control study to investigate the effect of vitamin D receptor gene (VDR) gene single nucleotide polymorphisms (SNPs) and possible gene- environment interaction on the susceptibility of renal cell carcinoma (RCC).

Methods: Generalized multifactor dimensionality reduction (GMDR) was used to find out the interaction combinations between SNPs and environmental factors, including gene- gene synergy and gene environment synergy effect. Logistic regression was used to analyze the correlation between the four SNPs in VDR gene and RCC, and the significant interaction combinations found by GMDR model were analyzed by hierarchical analysis.

Results: The genotype distribution of the control group was in accordance with Hardy- Weinberg equilibrium. Logistic regression analysis showed that the risk of RCC in VDR-rs7975232 A allele carriers was significantly higher than that of CC genotype carriers (CA + AA vs. CC), adjusted OR (95\% Cl) =1.75 (1.26-2.28). We used GMDR model to screen the best synergistic model between the four SNPs of VDR gene and smoking and drinking. We found a significant two locus model $(P=0.0010)$ involving rs7975232 and smoking. The cross- validation consistency of the two- locus model was 10/ 10, and the accuracy was 60.72\%. Compared with non-smokers with rs7975232 -CA or AA genotype, smokers with rs7975232 -CC genotype had the highest risk of RCC, or $(95 \% \mathrm{Cl})=2.23(1.42-3.09)$, after adjustment for covariates.
\end{abstract}

Conclusions: We found that the A allele of rs7975232 within VDR gene, interaction between rs7975232 and smoking were all associated with increased RCC risk.

Keywords: Alcohol drinking, Renal cell carcinoma, Vitamin D receptor, Single nucleotide polymorphisms, Interaction, Smoking

\section{Introduction}

Renal cell carcinoma is one of the most common malignant tumors in urinary system and one of the most lethal tumors [1]. There were 40,3262 newly diagnosed tumors in kidney, and 17, 5098 persons died from this cancer worldwide in 2018 [2]. And in China, there are too many new kidney cancer cases died from kidney

\footnotetext{
* Correspondence: lixiaojj226@163.com

Department of Urology, Linyi cancer hospital, No.6 Lingyuan East Street, Lanshan District, Shandong Province, Linyi Clty, China
}

cancer in 2016 [3]. Both the incidence and the corresponding mortality rate have been steadily increasing over the past several years [4]. Several risk factors related RCC risk were reported previously, including smoking, obesity, hypertension, acetaminophen and viral hepatitis [5-7]. Approximately, 4\% of all RCC are hereditary as well [8].

Previous epidemiological and biological studies have shown that vitamin D levels have a significant impact on the occurrence and development of cancer [9]. Vitamin

(C) The Author(s). 2021 Open Access This article is licensed under a Creative Commons Attribution 4.0 International License, which permits use, sharing, adaptation, distribution and reproduction in any medium or format, as long as you give appropriate credit to the original author(s) and the source, provide a link to the Creative Commons licence, and indicate if changes were made. The images or other third party material in this article are included in the article's Creative Commons licence, unless indicated otherwise in a credit line to the material. If material is not included in the article's Creative Commons licence and your intended use is not permitted by statutory regulation or exceeds the permitted use, you will need to obtain permission directly from the copyright holder. To view a copy of this licence, visit http://creativecommons.org/licenses/by/4.0/ The Creative Commons Public Domain Dedication waiver (http://creativecommons.org/publicdomain/zero/1.0/) applies to the data made available in this article, unless otherwise stated in a credit line to the data. 
D receptor (VDR) genetic polymorphisms, which located on chromosome 12q12-q14, could control Vitamin D activity, have been reported to be associated with several diseases [10-12]. The name of each SNP in VDR is based on the restriction site originally used to identify it. Such as FokI and BsmI, as defined by the endonucleases FokI and BsmI, respectively, have been most frequently studied in the previous studies. Previously, several studies [13-16] have been performed to evaluate the association between VDR polymorphisms and RCC risk in different populations, including several meta- analysis studies; however, the results of these studies were conflict. In addition, previous studies have shown that the occurrence and development of RCC is a multi-step, complex and complex process involving multiple environmental factors, genetic factors and the synergy between genetic factors and environmental factors $[17,18]$. However, up to now, there is no study on the relationship between VDR gene and environmental factors and the risk of renal cell carcinoma. Therefore, we designed a case-control study to investigate the effect of VDR gene SNPs and possible gene- environment interaction on the susceptibility of RCC.

\section{Materials and methods \\ Subjects}

A total of 1101 participants (634 males, 467 females) were selected, including 366 RCC patients and 735 control participants. All cases were primary renal cell carcinoma, and they were diagnosed by histopathology in our hospital. Those cases who had received any radiotherapy, chemotherapy or with any type of cancer were excluded from our study. Controls were cancer-free and were age- (less than 3 years) and sex-matched (nearly 1 : 2 matched) to patients. And those with any type of cancer, coronary heart disease, stroke and others history of serious diseases were excluded from control group. The subjects will participate in our questionnaire survey to obtain their general demographic information, lifestyle information and family history. Current drinking is defined as people who drink more than one type of alcoholic beverage per month, and the rest are non- drinkers. Current smokers were defined as those who smoked at least 100 cigarettes and still did not quit smoking at the time of filling out the questionnaire; people without a history of smoking were considered never to smoke. Each participant understood the process of the study and signed a written informed consent before the start of the study.

\section{Genotyping}

A total of 4 SNPs within VDR gene were selected for genotyping, including: rs7975232, rs2228570, rs1544410 and rs731236. Genomic DNA from participants was extracted from EDTA-treated whole blood, using the DNA Blood Mini Kit (Qiagen, Hilden, Germany) according to the manufacturer's instructions and stored at $-20{ }^{\circ} \mathrm{C}$ until use. The polymerase chain reaction-restriction fragment length polymorphism (PCR-RFLP) was performed to detect the polymorphisms of these 4 SNPs (Table 1), according previous study [19].

\section{Statistical analysis}

The mean and standard deviation (SDs) of normal distribution continuous variables were calculated, and the differences of continuous variables between case group and control group were compared by Student $t$ test. For categorical variables, we calculated the percentages and compared the differences between the case group and the control group using the chi square test. Generalized multifactor dimensionality reduction (GMDR) was used to find out the interaction combinations between SNPs and environmental factors, including gene- gene synergy and gene environment synergy effect, and in this model, some factors could be selected for adjustment, including gender, age, hypertension, diabetes, smoking or alcohol drinking and BMI. Logistic regression was used to analyze the correlation between the four SNPs in VDR gene and RCC, and the significant interaction combinations found by GMDR model were analyzed by hierarchical analysis. The $P$ values listed in all the results were double tailed, and those with $\mathrm{P}$ values less than 0.05 were considered to be statistically significant.

Table 1 Description and primers for 4 SNPs within VDR gene used for PCR analysis

\begin{tabular}{|c|c|c|c|c|c|c|}
\hline$\overline{S N P}$ & Chromosome & Functional Consequence & Annealing temp. & Alleles & $\begin{array}{l}\text { Restriction } \\
\text { enzymes }\end{array}$ & Primer sequences \\
\hline Fokl rs2228570 & $12: 47,879,112$ & Missense & $72.5^{\circ} \mathrm{C}$ & $C>T$ & Fokl & $\begin{array}{l}\text { F: GCACTGACTCTGGCTCTGAC } \\
\text { R: ACCCTCCTGCTCCTGTGGCT }\end{array}$ \\
\hline $\begin{array}{l}\text { Apal } \\
\text { rs7975232 }\end{array}$ & $12: 47,845,054$ & Intron variant & $66.0^{\circ} \mathrm{C}$ & $C>A$ & Apal & $\begin{array}{l}\text { F: CAGAGCATGGACAGGGAGCAA } \\
\text { R: GCAACTCCTCATGGCTGAGGTCTC }\end{array}$ \\
\hline Taql rs731236 & $12: 47,844,974$ & $\begin{array}{l}\text { Coding sequence variant, } \\
\text { synonymous variant }\end{array}$ & $51.9^{\circ} \mathrm{C}$ & $\mathrm{T}>\mathrm{C}$ & Taql & $\begin{array}{l}\text { F:5'- CCTGTGCCTTCTTCTCTAT - 3' } \\
\text { R: 5'- CTAGCTTCTGGATCATCTTG- 3' }\end{array}$ \\
\hline Bsm/ rs 1544410 & $12: 47,846,052$ & Intron variant & $50.5^{\circ} \mathrm{C}$ & $G>A$ & BsmFl & $\begin{array}{l}\text { F: 5'- ATATAGGCAGAACCATCTCT - 3' } \\
\text { R: 5'- TCTGAGGAACTAGATAAGCA - 3' }\end{array}$ \\
\hline
\end{tabular}




\section{Results}

A total of 1101 eligible subjects (634 males and $467 \mathrm{fe}-$ males) were selected, including 366 eligible RCC patients and 735 normal control subjects. The average age of all subjects was $63.2 \pm 14.2$ years. Table 2 lists the general clinical and demographic characteristics of different subjects in the case and control groups. There was no significant difference in age, body mass index and male ratio between the case group and the control group. However, the prevalence of smoking and drinking, hypertension and diabetes in the case group were significantly higher than those in the control group.

The genotype distribution of the control group was in accordance with Hardy Weinberg equilibrium. The A allele frequency of rs7975232 in RCC patients was $29.9 \%$, which was significantly higher than that in controls (20.0\%). Logistic regression analysis showed that the risk of RCC in vdr-rs7975232 A allele carriers was significantly higher than that of $\mathrm{CC}$ genotype carriers (CA + AA vs. CC), adjusted OR $(95 \% \mathrm{CI})=1.75$ (1.26-2.28). However, we also found that rs2228570, rs1544410 and rs731236 were not significantly associated with RCC risk, adjusted for covariates. (Table 3)

We used GMDR model to screen the best synergistic model between the four SNPs of VDR gene and smoking and drinking. Table 4 lists the best interaction combinations in each dimension of GMDR analysis. We found a significant two locus model $(P=0.0010)$ involving rs7975232 and smoking. The cross- validation consistency of the two- locus model was $10 / 10$, and the accuracy was $60.72 \%$. However, we did not find any significant synergistic effect combination in GMDR model of SNP and alcohol drinking interaction. We also used logistic regression

Table 2 General characteristics of 1101 study participants in RCC patients and controls

\begin{tabular}{llll}
\hline Variables & $\begin{array}{l}\text { Case group } \\
(\boldsymbol{n}=\mathbf{3 6 6})\end{array}$ & $\begin{array}{l}\text { Normal group } \\
(\boldsymbol{n}=\mathbf{7 3 5})\end{array}$ & $\boldsymbol{p}$-values \\
\hline Age (year) (Means \pm SD) & $62.8 \pm 12.5$ & $63.5 \pm 13.2$ & 0.399 \\
BMI (kg/m²) (Means \pm SD) & $23.6 \pm 8.6$ & $23.2 \pm 8.9$ & 0.478 \\
Gender & & & 0.675 \\
Males, N (\%) & $214(58.5)$ & $420(57.1)$ & \\
Females, N (\%) & $152(41.5)$ & $315(42.9)$ & \\
Smoking & & & 0.0084 \\
Current smokers, N (\%) & $100(27.3)$ & $149(20.3)$ & \\
Never or past smokers, N (\%) & $266(72.7)$ & $586(79.7)$ & 0.029 \\
Alcohol consumption & & & \\
Current drinkers, N (\%) & $117(32.0)$ & $189(25.7)$ & 0.004 \\
Never or past drinkers, N (\%) & $249(68.0)$ & $546(74.3)$ & 0.035 \\
Diabetes, N (\%) & $59(16.1)$ & $74(10.1)$ & \\
Hypertension, N (\%) & $105(28.7)$ & $168(22.9)$ & \\
Family history of cancer N (\%) & $60(16.4)$ & - & \\
\hline & & & \\
\hline
\end{tabular}

to analyze the synergistic effect between VDR-rs7975232 and smoking. We found that compared with non-smokers with rs7975232 -CA or AA genotype, smokers with rs7975232 -CC genotype had the highest risk of RCC, or $(95 \% \mathrm{CI})=2.23(1.42-3.09)$, after adjustment for covariates (Fig. 1).

\section{Discussion}

In our study, we found that the A allele of rs7975232 within VDR gene were significantly associated with increased RCC risk. However, we also found that rs2228570, rs1544410 and rs731236 were not significantly associated with RCC risk, adjusted for covariates. Several previous studies have reported the association between polymorphisms in VDR SNPs and risk of cancer, such as breast cancer and its survivors [20], colorectal cancer [21], lung cancer [22], advanced gallbladder cancer [23], bladder cancer [24], gastric cancer [25] and oral cancer [26]. To date, limited number of studies on relationship between VDR SNPs and RCC risk were performed, in addition, these previous studies could not obtain consistent results. Some previous studies have verified the relationship between genetic variation of $V D R$ and $R C C$ risk. Obara et al. [27] performed a case- control study suggested that AA genotype of ApaI locus in VDR gene may be a risk factor and poor prognosis factor of renal cell carcinoma in Japanese population. Arjumand et al. [13] indicated that FokI FF and VDR BB increased the cumulative risk of RCC by 1.87 times. Ou et al. [14] performed a casecontrol study suggested that the minor alleles of ApaI, Fok1, BsmI BB genotype, Fok1 gene were statistically associated with the susceptibility to RCC in Asians. Lin et al. [16] suggested that ApaI gene polymorphism and Fok1 FF genotype were associated with RCC susceptibility in Asians. Yang et al. [19] also indicated that VDR ApaI gene mutation was associated with increased risk and susceptibility to RCC in Chinese Han population. Recently, a meta- analysis [15] obtained similar results with forementioned studies. In current study, we did not find any relationship of FokI, TaqI and BsmI with RCC risk, but we found a significant relation between ApaI and RCC risk. Our results are inconsistent with other studies mentioned earlier, which may be due to the differences in genetic background, PD definition, sample size and statistical ability of the investigated population. In addition, these inconsistent results are also affected by multiple genetic heterogeneity, population mixing, gene environment and gene- gene interactions.

RCC susceptibility was influenced not only by environmental factors, genetic factors, but also by the gene- environment interactions. Previous studies have reported several risk factors significantly associated with RCC susceptibility, including hypertension, active or passive smoking, alcohol consumption and obesity [17, 28, 29]. 
Table 3 The association between 4 SNPs within VDR gene and RCC risk

\begin{tabular}{|c|c|c|c|c|c|}
\hline \multirow[t]{2}{*}{ SNP } & \multirow{2}{*}{$\begin{array}{l}\text { Genotypes } \\
\text { and Alleles }\end{array}$} & \multicolumn{2}{|l|}{ Frequencies $\mathrm{N}(\%)$} & \multirow[t]{2}{*}{ OR $(95 \% C l)^{a}$} & \multirow{2}{*}{$\begin{array}{l}\text { HWE } \\
\text { test for } \\
\text { controls }\end{array}$} \\
\hline & & Controls $(n=735)$ & Cases $(n=366)$ & & \\
\hline \multirow[t]{6}{*}{ rs2228570 (Fokl) } & & & & & 0.997 \\
\hline & $\mathrm{CC}$ & $432(58.8)$ & $191(52.2)$ & 1.00 (ref) & \\
\hline & $\mathrm{CT}$ & $263(35.8)$ & $143(39.1)$ & $1.32(0.91-1.83)$ & \\
\hline & $\pi$ & $40(5.4)$ & $32(8.7)$ & $1.55(0.72-2.42)$ & \\
\hline & $C T+\pi$ & $303(41.2)$ & $175(47.8)$ & $1.39(0.86-1.93)$ & \\
\hline & Allele, T (\%) & $343(23.3)$ & $207(28.3)$ & & \\
\hline \multirow[t]{6}{*}{ rs7975232 (Apal) } & & & & & 0.289 \\
\hline & $\mathrm{CC}$ & $475(64.6)$ & $182(49.7)$ & 1.00 (ref) & \\
\hline & CA & $226(30.7)$ & $149(40.7)$ & $1.63(1.21-2.04)$ & \\
\hline & $\mathrm{AA}$ & $34(4.6)$ & 35 (9.6) & $2.02(1.47-2.62)$ & \\
\hline & $C A+A A$ & $260(35.4)$ & $184(50.3)$ & $1.75(1.26-2.28)$ & \\
\hline & Allele, A (\%) & $294(20.0)$ & $219(29.9)$ & & \\
\hline \multirow[t]{6}{*}{ rs731236 (Taql) } & & & & & 0.735 \\
\hline & $\pi$ & $460(62.6)$ & $200(54.6)$ & 1.00 (ref) & \\
\hline & $\mathrm{TC}$ & $241(32.8)$ & $139(38.0)$ & $1.24(0.92-1.65)$ & \\
\hline & $\mathrm{CC}$ & $34(4.6)$ & $27(7.4)$ & $1.31(0.81-1.86)$ & \\
\hline & $\mathrm{TC}+\mathrm{CC}$ & $275(37.4)$ & $166(45.4)$ & $1.26(0.89-1.69)$ & \\
\hline & Allele, C (\%) & $309(21.0)$ & $193(26.4)$ & & \\
\hline \multirow[t]{6}{*}{ rs1544410 (Bsml) } & & & & & 0.655 \\
\hline & GG & $466(63.4)$ & $211(57.7)$ & 1.00 (ref) & \\
\hline & GA & $236(32.1)$ & $130(35.5)$ & $1.31(0.87-1.79)$ & \\
\hline & $\mathrm{AA}$ & $33(4.5)$ & $25(7.8)$ & $1.45(0.78-2.15)$ & \\
\hline & $G A+A A$ & $269(36.6)$ & $155(42.3)$ & $1.34(0.84-1.87)$ & \\
\hline & Allele, A (\%) & $302(20.5)$ & $180(24.6)$ & & \\
\hline
\end{tabular}

${ }^{\mathrm{a} A d j u s t e d ~ f o r ~ g e n d e r, ~ a g e, ~ h y p e r t e n s i o n, ~ d i a b e t e s, ~ s m o k i n g, ~ a l c o h o l ~ d r i n k i n g ~ a n d ~ B M I ~}$

Table 4 GMDR analysis on the best gene-environment interaction models

\begin{tabular}{|c|c|c|c|c|}
\hline Locus no. & Best combination & $\begin{array}{l}\text { Cross-validation } \\
\text { consistency }\end{array}$ & Testing accuracy & $p$-values \\
\hline \multicolumn{5}{|c|}{ Gene- alcohol drinking interactions $^{\mathrm{a}}$} \\
\hline 2 & 1,5 & $9 / 10$ & 0.572 & 0.055 \\
\hline 3 & $1,2,5$ & $7 / 10$ & 0.540 & 0.172 \\
\hline 4 & $1,2,4,5$ & $6 / 10$ & 0.423 & 0.377 \\
\hline 5 & $1,2,4,3,5$ & $6 / 10$ & 0.496 & 0.426 \\
\hline \multicolumn{5}{|c|}{ Gene- smoking interactions ${ }^{b}$} \\
\hline 2 & 1,6 & $10 / 10$ & 0.607 & 0.001 \\
\hline 3 & $1,3,6$ & $8 / 10$ & 0.540 & 0.172 \\
\hline 4 & $1,3,2,6$ & $7 / 10$ & 0.487 & 0.623 \\
\hline 5 & $1,3,2,4,6$ & $6 / 10$ & 0.478 & 0.989 \\
\hline
\end{tabular}

a Adjusted for gender, age, hypertension, diabetes, smoking and BMI

${ }^{\mathrm{b}}$ Adjusted for gender, age, hypertension, diabetes, drinking and BMI

rs7975232, rs2228570, rs1544410, rs731236, current alcohol drinking and current smoking were symbolized as 1-6, respectively 


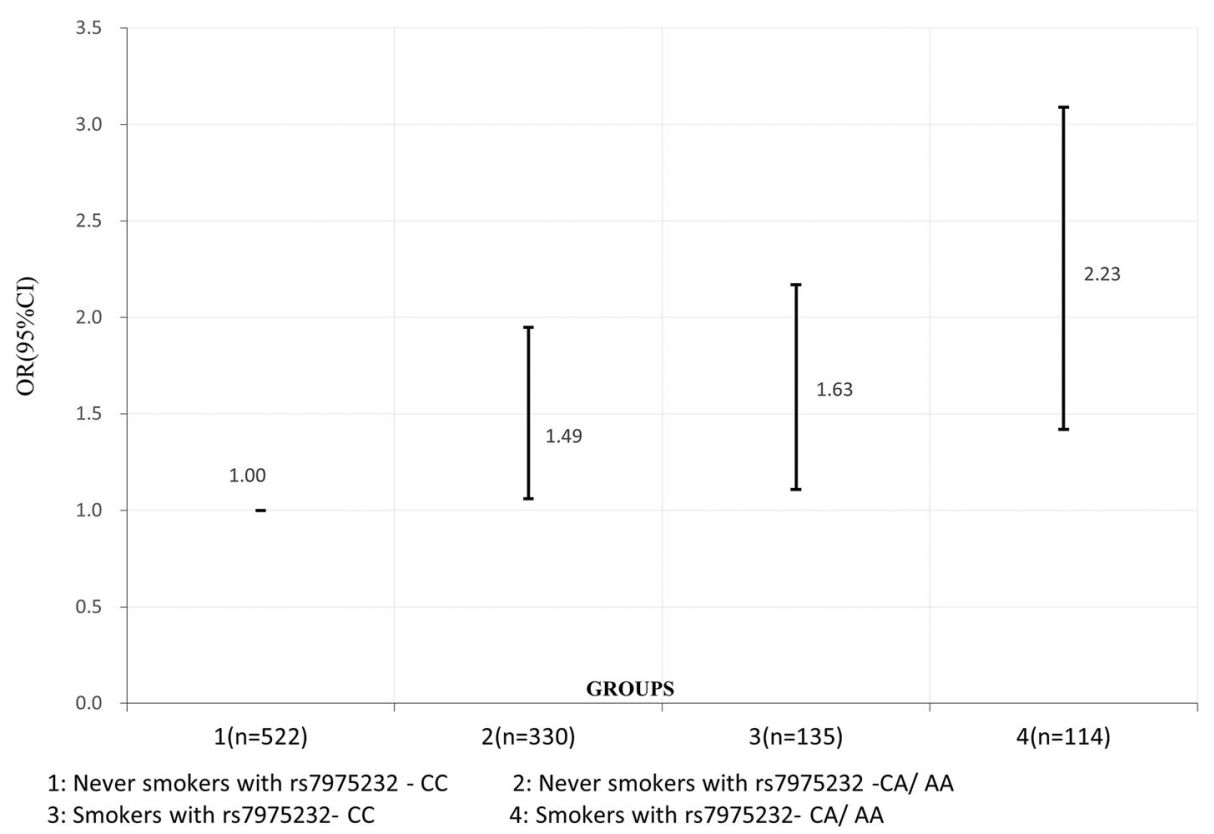

Fig. 1 Hierarchical analysis for rs7975232 - alcohol drinking interaction using logistic regression. Hierarchical analysis for rs7975232- current smoking interaction using logistic regression

Among these factors, smoking and drinking are the two major modifiable risk factors for RCC. In this study, the smoking and drinking rates of RCC patients were significantly higher than those of the control group. Therefore, six variables, including four SNPs and two environmental factors (current smoking and current drinking) were included in the GMDR model, we found a significant two locus model $(P=0.0010)$ involving rs7975232 and smoking. We also used logistic regression to analyze the synergistic effect between VDR-rs7975232 and smoking, compared with non-smokers with rs7975232 -CA or AA genotype, smokers with rs7975232 -CC genotype had the highest risk of RCC. However, we did not find any significant synergistic effect combination in GMDR model of SNP and alcohol drinking interaction. Previously, the gene- environment interaction on RCC risk has been reported between VEGF gene and smoking in two studies $[30,31]$. But to date, no studies reported the impact of interaction between VDR gene and smoking on RCC risk in Chinese populations. The significant interaction between rs7975232 and smoking indicated that the RCC susceptibility could be influenced by comprehensive factors, which including VDR- rs7975232, environment factors, such as smoking, and the interaction between rs7975232 and smoking. The biological mechanism of the interaction between rs7975232 and smoking is not very clear. We believe that the degree of association between rs7975232 and RCC risk is influenced by smoking status.

Although our study is important for us to understand the genetic susceptibility of RCC, there are still several limitations in this study. Firstly, this study only selected a few common SNPs, more SNPs should be included in the study. Secondly, more environmental factors should be included in GMDR model to explore more gene environment interaction combinations. Thirdly, the results of this study still need to be verified in other studies with larger sample size. Lastly, participants included in this study were all Chinese Han population, so the results obtained in our study need to be verified in different populations, ethnicities and SNPs in the VDR gene.

In conclusion, we found that both the A allele of rs7975232 within VDR gene, rs7975232 and smoking were statistically associated with increased RCC risk.

\section{Acknowledgements}

We thank the investigators and staffs from our Hospital, and all the partners and staffs who help us in the process of this study.

\section{Authors' contributions}

Manuscript preparation, editing and review were conducted by TJ and LX; LJ and WW participated in the interpretation of the studies and experiment; ZS conducted study concepts and study design; guarantor of integrity of the entire study; data analysis and statistical analysis were conducted by WY. The author(s) read and approved the final manuscript.

\section{Funding}

No source of funding supported this study.

\section{Availability of data and materials}

The datasets generated and/or analyzed during the current study are available from the corresponding author on reasonable request. 


\section{Declarations}

\section{Ethics approval and consent to participate}

this study has been approved by ethics committee of the Linyi cancer hospital (NO.)

\section{Consent for publication}

Not applicable.

\section{Competing interests}

There is no conflict of interest.

Received: 5 January 2021 Accepted: 27 March 2021

Published online: 18 May 2021

\section{References}

1. Jemal A, Siegel R, Ward E, Hao Y, Xu J, Thun MJ. Cancer statistics, 2009. CA Cancer J Clin. 2009;59(4):225-49.

2. Bray F, Ferlay J, Soerjomataram I, Siegel RL, Torre LA, Jemal A. Global cancer statistics 2018: GLOBOCAN estimates of incidence and mortality worldwide for 36 cancers in 185 countries. CA Cancer J Clin. 2018;68(6):394-424.

3. Feng RM, Zong YN, Cao SM, Xu RH. Current cancer situation in China: good or bad news from the 2018 Global Cancer Statistics? Cancer Commun (Lond). 2019:39(1):22

4. Rini BI, Campbell SC, Escudier B. Renal cell carcinoma. Lancet. 2009;373: 1119-32.

5. Sun M, Becker A, Tian Z, Roghmann F, Abdollah F, Larouche A, Karakiewicz $\mathrm{PI}$, Trinh QD. Management of localized kidney cancer: calculating cancerspecific mortality and competing risks of death for surgery and nonsurgical management. Eur Urol. 2014;65(1):235-41.

6. Masson-Lecomte A, Yates DR, Hupertan V, Haertig A, Chartier-Kastler E, Bitker MO, Vaessen C, Rouprêt M. A prospective comparison of the pathologic and surgical outcomes obtained after elective treatment of renal cell carcinoma by open or robot-assisted partial nephrectomy. Urol Oncol. 2013;31(6):924-9.

7. Choi JE, You JH, Kim DK, Rha KH, Lee SH. Comparison of perioperative outcomes between robotic and laparoscopic partial nephrectomy: a systematic review and meta-analysis. Eur Urol. 2015;67(5):891-901.

8. Clifford SC, Prowse AH, Affara NA, Buys CH, Maher ER. Inactivation of the von Hippel-Lindau (VHL) tumour suppressor gene and allelic losses at chromosome arm $3 p$ in primary renal cell carcinoma: evidence for a VHLindependent pathway in clear cell renal tumourigenesis. Genes Chromosomes Cancer. 1998;22(3):200-9.

9. Raimondi S, Johansson H, Maisonneuve P, Gandini S. Review and metaanalysis on vitamin $\mathrm{d}$ receptor polymorphisms and cancer risk. Carcinogenesis. 2009:30:1170.

10. Vasilovici AF, Grigore LE, Ungureanu L, Fechete $O$, Candrea E, Trifa AP, Vișan S, Senilă S, Cosgarea R. Vitamin D receptor polymorphisms and melanoma. Oncol Lett. 2019;17(5):4162-9.

11. Li J, Chen SY, Liu HH, Yin XD, Cao LT, Xu JH, Li XM, Ye DQ, Wang J. Associations of Vitamin D Receptor Single Nucleotide Polymorphisms with Susceptibility to Systemic Sclerosis. Arch Med Res. 2019;50(6):368-76.

12. Gandini S, Gnagnarella P, Serrano D, Pasquali E, Raimondi S. Vitamin D receptor polymorphisms and cancer. Adv Exp Med Biol. 2014;810:69-105.

13. Arjumand W, Ahmad ST, Seth A, Saini AK, Sultana S. Vitamin D receptor Fokl and Bsml gene polymorphism and its association with grade and stage of renal cell carcinoma in North Indian population. Tumour Biol. 2012;33(1):23-31.

14. Ou C, Zhao HL, Zhu B, Huang LS, Li PZ, Lao M. Association of vitamin D receptor gene polymorphism with the risk of renal cell carcinoma: a metaanalysis. J Recept Signal Transduct Res. 2014;34(6):463-8.

15. Zhou T, Li H, Xie WJ, Zhong Z, Zhong H, Lin ZJ. Association of Methylenetetrahydrofolate Reductase, Vitamin D Receptor, and Interleukin16 Gene Polymorphisms With Renal Cell Carcinoma Risk. Technol Cancer Res Treat. 2019;18:1533033819859413.

16. Lin ZJ, Zhang XL, Yang ZS, She XY, Xie Y, Xie WJ. Relationship between Vitamin $D$ receptor gene polymorphism and renal cell carcinoma susceptibility. J Cancer Res Ther. 2018;14(4):820-5.

17. Wang G, Hou J, Ma L, Xie J, Yin J, Xu D, Chang W, Tan X, Su T, Zhang H, Cao G. Risk factor for clear cell renal cell carcinoma in Chinese population: a case-control study. Cancer Epidemiol. 2012;36(2):177-82.
18. Hunt JD, van der Hel OL, McMillan GP, Boffetta P, Brennan P. Renal cell carcinoma in relation to cigarette smoking: meta-analysis of 24 studies. Int J Cancer. 2005;114(1):101-8.

19. Yang C, Li J, Li Y, Wu D, Sui C, Jiang Y, Meng F. The vitamin D receptor gene Apal polymorphism is associated with increased risk of renal cell carcinoma in Chinese population. Sci Rep. 2016;6:25987.

20. Francis I, AlAbdali N, Kapila K, John B, Al-Temaimi RA. Vitamin D pathway related polymorphisms and vitamin $\mathrm{D}$ receptor expression in breast cancer. Int J Vitam Nutr Res. 2019: 1-9.

21. Messaritakis I, Koulouridi A, Sfakianaki M, Vogiatzoglou K, Gouvas N, Athanasakis E, Tsiaoussis J, Xynos E, Mavroudis D, Tzardi M, Souglakos J. The Role of Vitamin D Receptor Gene Polymorphisms in Colorectal Cancer Risk. Cancers (Basel). 2020;12(6):1379.

22. Li M, Liu X, Liu N, Yang T, Shi P, He R, Chen M. Association between Polymorphisms of Vitamin D Receptor and Lung Cancer Susceptibility: Evidence from an Updated Meta-analysis. J Cancer. 2019;10(16):3639-49.

23. Mittal S, Anand A, Vijayashankar A, Sonkar AA, Husain N, Chandra A. Vitamin D Receptor and Role of Vitamin D Supplementation in Advanced Gallbladder Cancer: A Prospective Study from Northern India. Gulf J Oncolog. 2019;1(31):14-20.

24. Baykan O, Akgul M, Uren N, Yaman A, Tinay I, Ergul E, Sazci A, Turkeri L, Haklar G. The Relationship Between Urothelial Type Bladder Cancer, Plasma 25-Hydroxyvitamin D Levels, and Vitamin D Receptor Apal Bsml Fokl, and Taql Polymorphisms. Clin Lab. 2019;65(4). doi:https://doi.org/10.7754/Clin.La b.2018.180339.

25. Parsamanesh N, Moossavi M, Tavakkoli T, Javdani H, Fakharian T, Moossavi SZ, Naseri M. Positive correlation between vitamin D receptor gene Taql variant and gastric cancer predisposition in a sample of Iranian population. J Cell Physiol. 2019. doi:https://doi.org/10.1002/jcp.28145.

26. Fathi N, Ahmadian E, Shahi S, Roshangar L, Khan H, Kouhsoltani M, Maleki Dizaj S, Sharifi S. Role of vitamin D and vitamin D receptor (VDR) in oral cancer. Biomed Pharmacother. 2019;109:391-401.

27. Obara W, Suzuki Y, Kato K, Tanji S, Konda R, Fujioka T. Vitamin D receptor gene polymorphisms are associated with increased risk and progression of renal cell carcinoma in a Japanese population. Int J Urol. 2007:14(6):483-7.

28. Cote ML, Colt JS, Schwartz KL, Wacholder S, Ruterbusch JJ, Davis F, Purdue M, Graubard Bl, Chow WH. Cigarette smoking and renal cell carcinoma risk among black and white Americans: effect modification by hypertension and obesity. Cancer Epidemiol Biomarkers Prev. 2012;21(5):770-9.

29. Antwi SO, Eckel-Passow JE, Diehl ND, Serie DJ, Custer KM, Wu KJ, Cheville JC, Thiel DD, Leibovich BC, Parker AS. Alcohol consumption, variability in alcohol dehydrogenase genes and risk of renal cell carcinoma. Int J Cancer. 2018;142(4):747-56.

30. Shen BL, Qu QS, Miao SZ, Zhang YX. Association between SNPs in vascular endothelial growth factor polymorphisms and risk of renal cell carcinoma: a case-control study. Genet Mol Res. 2015;14(3):11119-25.

31. Lu G, Dong Y, Zhang Q, Jiao L, Yang S, Shen B. Predictive value of vascular endothelial growth factor polymorphisms on the risk of renal cell carcinomas: a case-control study. Tumour Biol. 2015;36(11):8645-52.

\section{Publisher's Note}

Springer Nature remains neutral with regard to jurisdictional claims in published maps and institutional affiliations.

Ready to submit your research? Choose BMC and benefit from

- fast, convenient online submission

- thorough peer review by experienced researchers in your field

- rapid publication on acceptance

- support for research data, including large and complex data types

- gold Open Access which fosters wider collaboration and increased citations

- maximum visibility for your research: over $100 \mathrm{M}$ website views per year

At BMC, research is always in progress.

Learn more biomedcentral.com/submissions 